\title{
Simpler and Cleaner Synthesis of Variously Capped Cobalt Nanocrystals Applied in Semi-hydrogenation of Alkynes
}

\author{
A. Sodreau ${ }^{1}$, A. Vivien ${ }^{1}$, A. Moisset ${ }^{2}$, C. Salzemann ${ }^{2}$, C. Petit ${ }^{2}{ }_{*}^{*}$ and M. Petit ${ }^{*}$ \\ ${ }^{1}$ Sorbonne Université, CNRS, Institut Parisien de Chimie Moléculaire, UMR 8232, 4 place Jussieu, 75005 Paris, France. \\ ${ }^{2}$ Sorbonne Université, MONARIS, UMR 8233, 4 place Jussieu, 75005 Paris, France. \\ Cobalt, Nanoparticles, Disproportionation, Hcp phase, Semi-hydrogenation.
}

\begin{abstract}
Unlike the classical organometallic approach, we report here a synthetic pathway requiring no reducing sources or heating to produce homogenous hexagonal close packed cobalt nanocrystals (NCs). Involving a disproportionation process, this simple and fast $(6 \mathrm{~min})$ synthesis is performed at room temperature in presence of ecofriendly fatty alcohols to passivate Co NCs. Through a recycling step, the yield of Co NCs is improved and the waste generation is limited making this synthetic route cleaner. After an easy exchange of the capping ligands, we applied them as unsupported catalyst in the stereo-selective semi-hydrogenation of alkynes.
\end{abstract}

Author Contributions.................................................................................................................2

Experimental Procedures

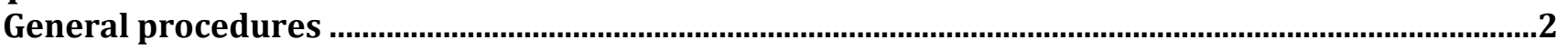

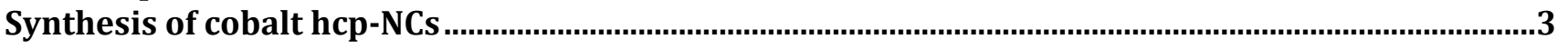

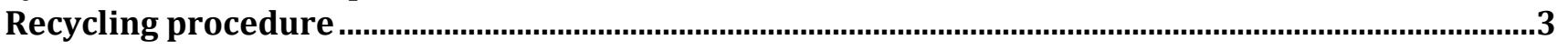

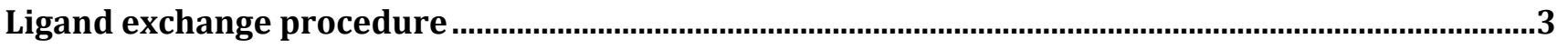

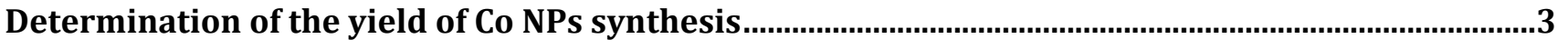

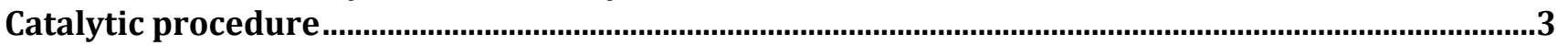

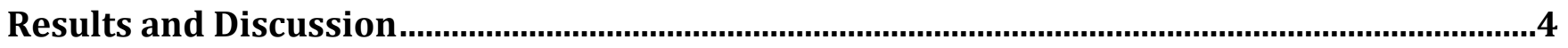

Scheme S1 of disproportionation mechanism for Cobalt NPs synthesis.................................................4

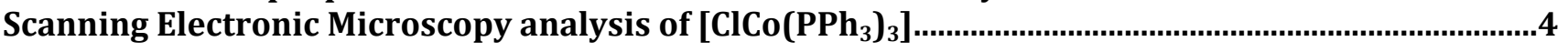

Microscopic characterization of preliminary synthesis....................................................................

High Resolution TEM characterization of the synthesis Cobalt NPs from [ClCo( $\left.\left.\mathrm{PPh}_{3}\right)_{3}\right]$ precursors

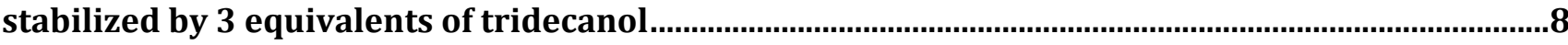

Microscopic characterization of the synthesis Cobalt NPs from [XCo( $\left.\left.\mathrm{PPh}_{3}\right)_{3}\right]$ precursors stabilized

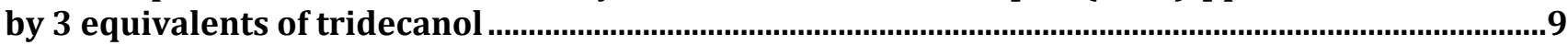

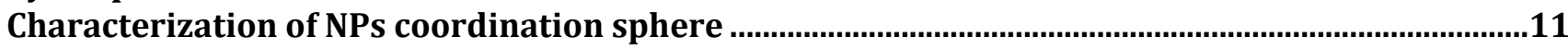

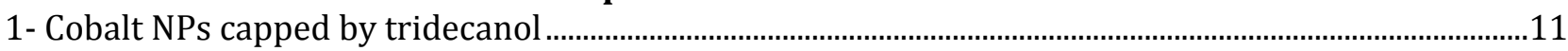

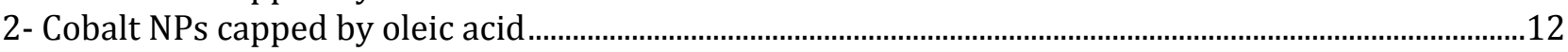

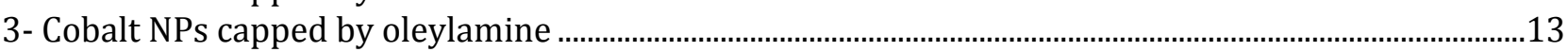

4- Cobalt NPs capped by trioctylphosphine .................................................................................................14

5- Cobalt NPs capped by trioctylphosphine oxide ..........................................................................................15

Figure S15. IR of Co nanoparticles after ligand exchange by trioctylphosphine oxide (TOPO) and

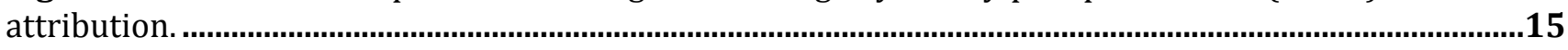

Magnetic characterization by VSM of Co NPs from [BrCo( $\left.\left(\mathrm{PPh}_{3}\right)_{3}\right]$ precursors ...................................16

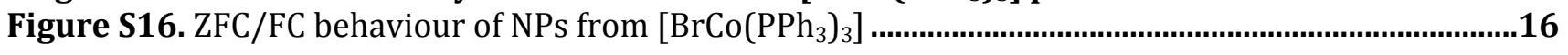

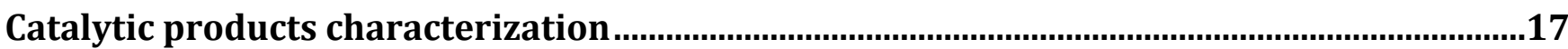




\section{Author Contributions}

AS and AV synthesized the organometallic complexes. AS did all the synthesis of the NCs and did the XRD, TEM, HRTEM and IR experiment. AV did the semi-hydrogenation reactions. AM did the VSM of the NCs. CP and MP supervised the students, designed the study, and the experiments. The first draft of the manuscript was written by AS under the supervision of MP. The draft of the magnetic study was written by AM under the supervision of $\mathrm{CP}$ and $\mathrm{CS}$. The manuscript was finalized through contributions of all authors. All authors have given approval to the final version of the manuscript.

\section{Experimental Procedures}

\section{General procedures}

$\mathrm{CoCl}_{2} \cdot 6 \mathrm{H}_{2} \mathrm{O}$ (Sigma-aldrich, 98\%), $\mathrm{PPh}_{3}$ (fluorochem, 95\%), $\mathrm{NaBH}_{4}$ (Acros Organic, 95\%) were commercially bought. Absolute ethanol and diethylether were degassed. THF was distillated under nitrogen then dried over molecular sieves $4 \AA$ (Sigma-Aldrich) and finally degassed under Argon.

Preparation of $\left[\mathrm{ClCo}\left(\mathrm{PPh}_{3}\right)_{3}\right]$ : On $9.6 \mathrm{~g}$ of $\mathrm{CoCl}_{2} \cdot 6 \mathrm{H}_{2} \mathrm{O}$, $(40 \mathrm{mmoles})$ and $32.0 \mathrm{~g}$ of triphenylphosphine (122 mmoles) were added $600 \mathrm{ml}$ of degassed ethanol. The resulting heterogeneous solution was stirred vigorously at $60-70^{\circ} \mathrm{C}$ for 30 minutes environ to form in situ the complex $\mathrm{Cl}_{2}\left(\mathrm{PPh}_{3}\right)_{2} \mathrm{Co}$ (II) as a bright blue powder. The mixture was then cool down to $30^{\circ} \mathrm{C}$ and $1.28 \mathrm{~g}$ of sodium borohydride were added (34 mmoles) in 10 portions every 10 minutes. The color of the mixture changed from bright blue to dark brown. After 2 hours the brown precipitate was filtrated, washed sequentially with ethanol and diethyl ether and was finally dried under vaccum to give $25 \mathrm{~g}$ of the desired $\left[\mathrm{ClCo}\left(\mathrm{PPh}_{3}\right)_{3}\right]$ complex with $75 \%$ yield.

Samples Characterization: A $100 \mathrm{kV}$ transmission electron microscope (TEM, JEOL JEM-1011 with a digital camera Gatan) was used to characterize cobalt nanocrystals and their assemblies (low magnification bright field picture, Selected Area Electron Diffraction, SAED). A $200 \mathrm{kV}$ transmission electron microscope (TEM, JEOL JEM 2100 with a digital camera Gatan) was used for High Resolution TEM picture. To observe the nanoparticles, $10 \mu \mathrm{L}$ of the solution containing dispersed nanoparticles in toluene were deposited on a TEM grid, followed by evaporation of solvent in order to form a nanoparticle film.

Hysteresis Loops at $3 \mathrm{~K}$ and $300 \mathrm{~K}$ of the Cobalt NCs magnetization were measured with a commercial SQUID magnetometer (Cryogenic S600) with applied fields up to $4 \mathrm{~T}$. Nanomaterials are aggregated on an silicon wafer.

The final nanoparticle solution was dried under vacuum and the resulting powder was analysed by infrared (Bruker Alpha-p).

X-Ray Diffraction (XRD) analysis was performed by D8 Advance Bruker with a copper source $(\lambda=$ $1.5404 \AA$ ). The sample was introduced in a borosilcate tube in a glovebox (Mbraun) and sealed by torch. 


\section{Synthesis of cobalt hep-NCs}

$132 \mathrm{mg}$ of $\left[\mathrm{ClCo}\left(\mathrm{PPh}_{3}\right)_{3}\right](0,15 \mathrm{mmol})$ was loaded in a screw-capped tube of $12 \mathrm{~mL}$ with a magnetic bar. In another tube, $90 \mathrm{mg}$ of tridecanol $(0,45 \mathrm{mmol})$ was dissolved in $6 \mathrm{~mL}$ of THF. Then, the solution of tridecanol was poured on $\left[\mathrm{ClCo}\left(\mathrm{PPh}_{3}\right)_{3}\right]$ under magnetic stirring. The solution color changed quickly from brown to black. After 6 minutes, about $15 \mathrm{~mL}$ of EtOH was added to the black solution and centrifuged at $2500 \mathrm{RPM}$ for $5 \mathrm{~min}$. A black powder was observed at bottom of tube with a blue supernatant. After elimination of the supernatant, the nanoparticles were dispersed in $2 \mathrm{~mL}$ of toluene and a drop was laid on a copper TEM grid to perform microscopic characterization. NPs from $\left[\mathrm{BrCo}\left(\mathrm{PPh}_{3}\right)_{3}\right]$ and $\left[\mathrm{ICo}\left(\mathrm{PPh}_{3}\right)_{3}\right]$ are prepare with the same procedure and amount than the one for $\left[\mathrm{ClCo}\left(\mathrm{PPh}_{3}\right)_{3}\right]$ precursor.

\section{Recycling procedure}

After 10 standard reactions, all supernatants were collected and transferred in schlenk tube. Then, under argon, $26 \mathrm{mg}$ of $\mathrm{NaBH}_{4}$ (0.9 eq.) were introduced in portion over 30 minutes under a vigorous stirring. After 4 hours at RT, the dark brown solid formed was filtrated and washed 3 times by EtOH and finally once by $\mathrm{Et}_{2} \mathrm{O}$. The solid was dried giving $490 \mathrm{mg}$ of $\left[\mathrm{ClCo}\left(\mathrm{PPh}_{3}\right)_{3}\right]$.

\section{Ligand exchange procedure}

To a dispersed solution of NPs in toluene 20 eq. of oleylamine were added and mixed for 5 minutes. The excess of ligands was removed by a EtOH washing $(20 \mathrm{~mL})$.

\section{Determination of the yield of Co NPs synthesis}

To determine the yield of Co NPs synthesis, isolated Co NPs stabilized by tridecanol was heated under vacuum, first, by heat gun during 20 minutes and then in a sand bath at $250^{\circ} \mathrm{C}$ for $4 \mathrm{~h}$. The resulting black powder was weighed to give $42 \%$ of metallic cobalt.

\section{Catalytic procedure}

Under argon atmosphere, in a sealed tube was added 0.75 mmoles of the substrate with $2 \mathrm{~mL}$ of a toluene suspension containing $5 \mathrm{~mol} \%$ of Co NPs. Then the tube was introduced in an autoclave and filled with the desired pressure of hydrogen. The mixture was stirred and heated in an oil bath. At the end of the reaction the solution was filtered over silica and washed with pentane or ethyl acetate (depending on the polarity of the substrate). The solvent was removed under reduced pressure to give the desired compound.

The catalytic charge was evaluated by the following procedure: a synthesis of Co NPs contained initially $0.15 \mathrm{mmol}$ of cobalt complex and resulted in a solution containing a maximum of $0.075 \mathrm{mmol}$ of metallic cobalt in $4 \mathrm{~mL}$ of toluene (considering a full disproportionation process). For each catalytic reaction, $2 \mathrm{~mL}$ of this solution have been introduced into the reactor giving a maximum of $0.0375 \mathrm{mmol}$ of metallic cobalt (or $5 \mathrm{~mol} \%$ ). 


\section{Results and Discussion}

Scheme S1 of disproportionation mechanism for Cobalt NPs synthesis.

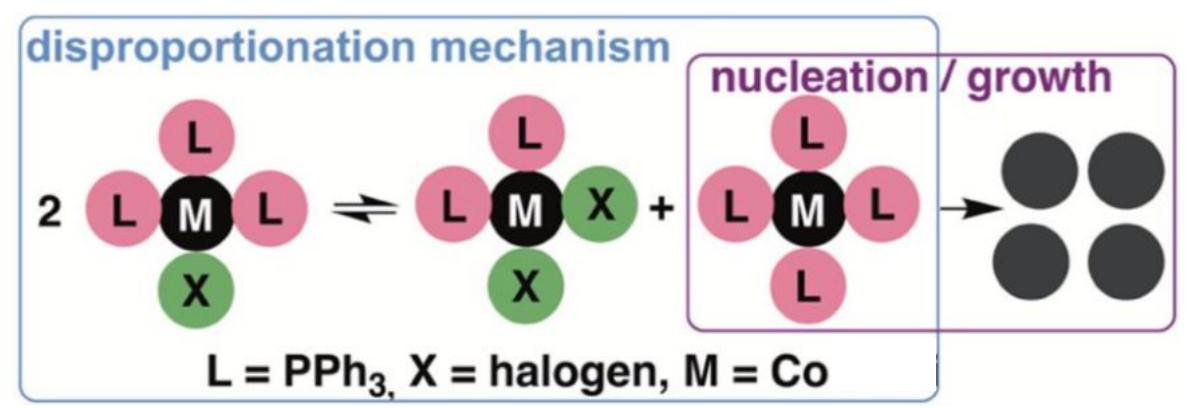

\section{Scanning Electronic Microscopy analysis of $\left[\mathrm{ClCo}\left(\mathrm{PPh}_{3}\right)_{3}\right]$}

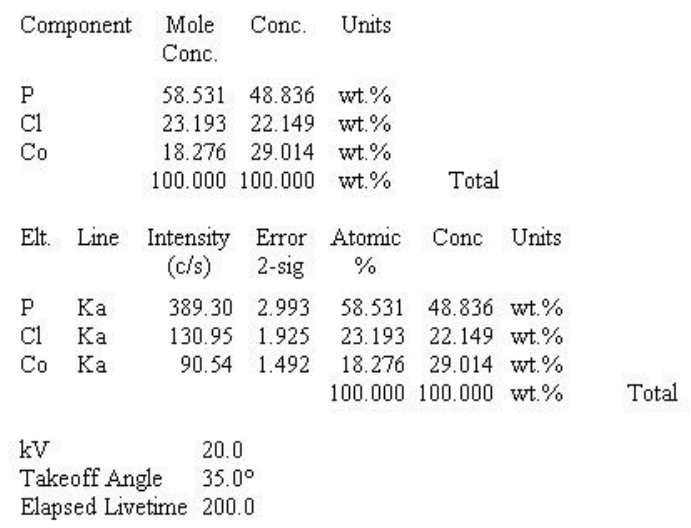

\section{Microscopic characterization of preliminary synthesis}

Table S1. TEM pictures of the synthesis of nanoparticles by $\left[\mathrm{ClCo}\left(\mathrm{PPh}_{3}\right)_{3}\right]$ disproportionation in THF at room temperature.

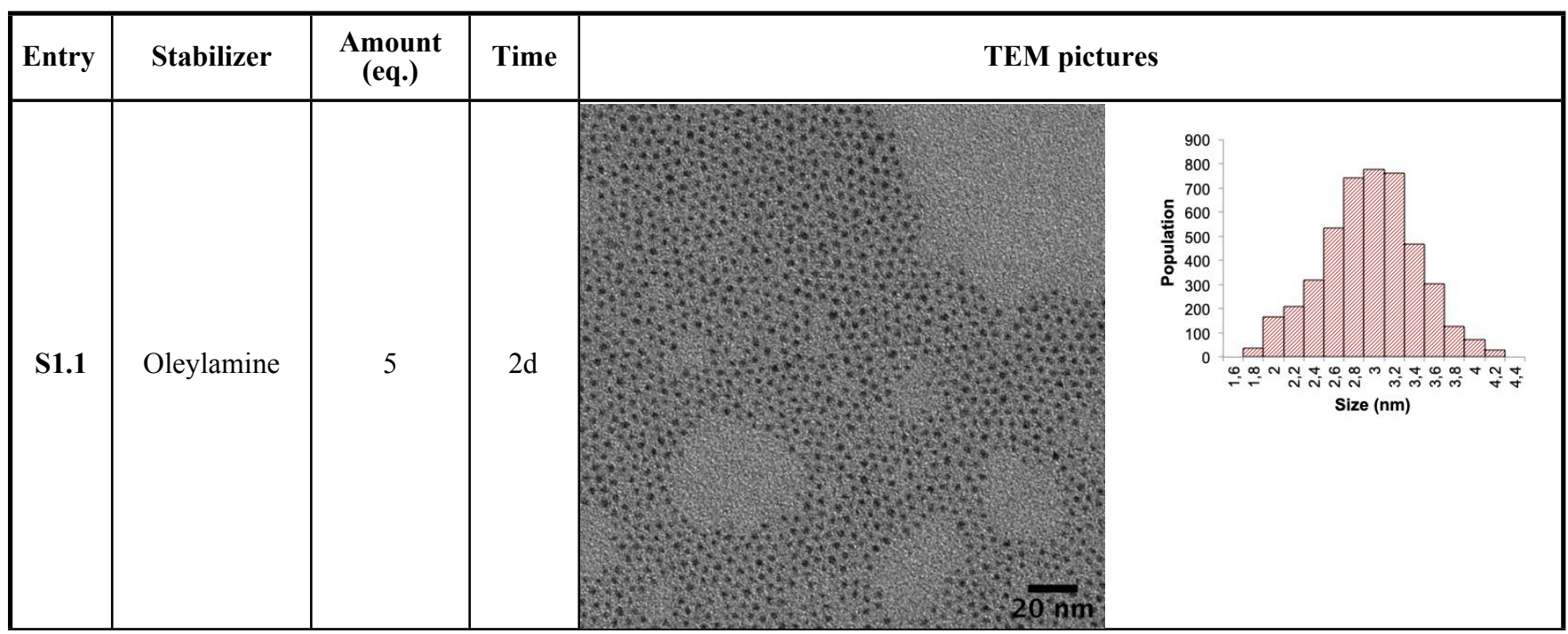




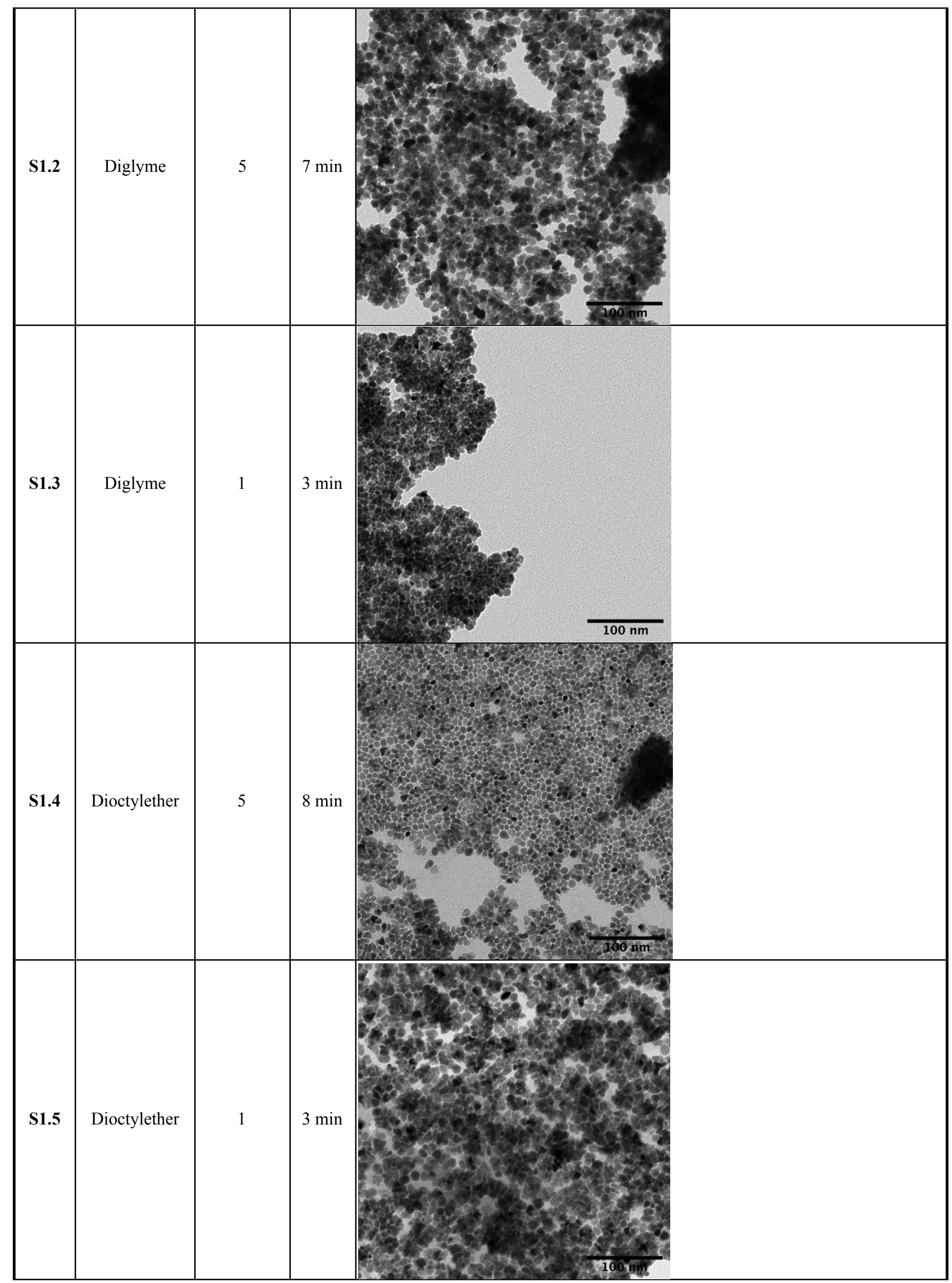




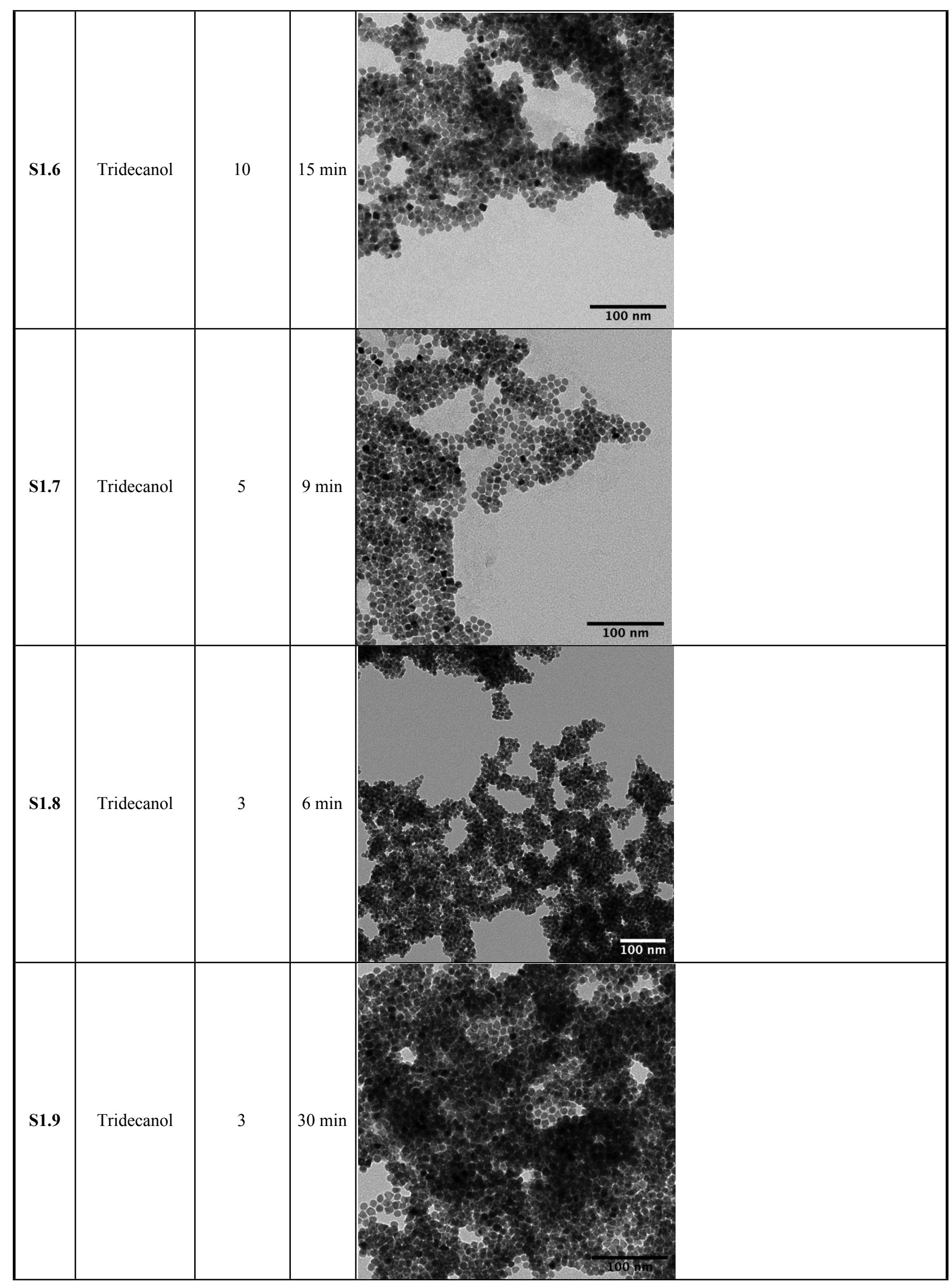




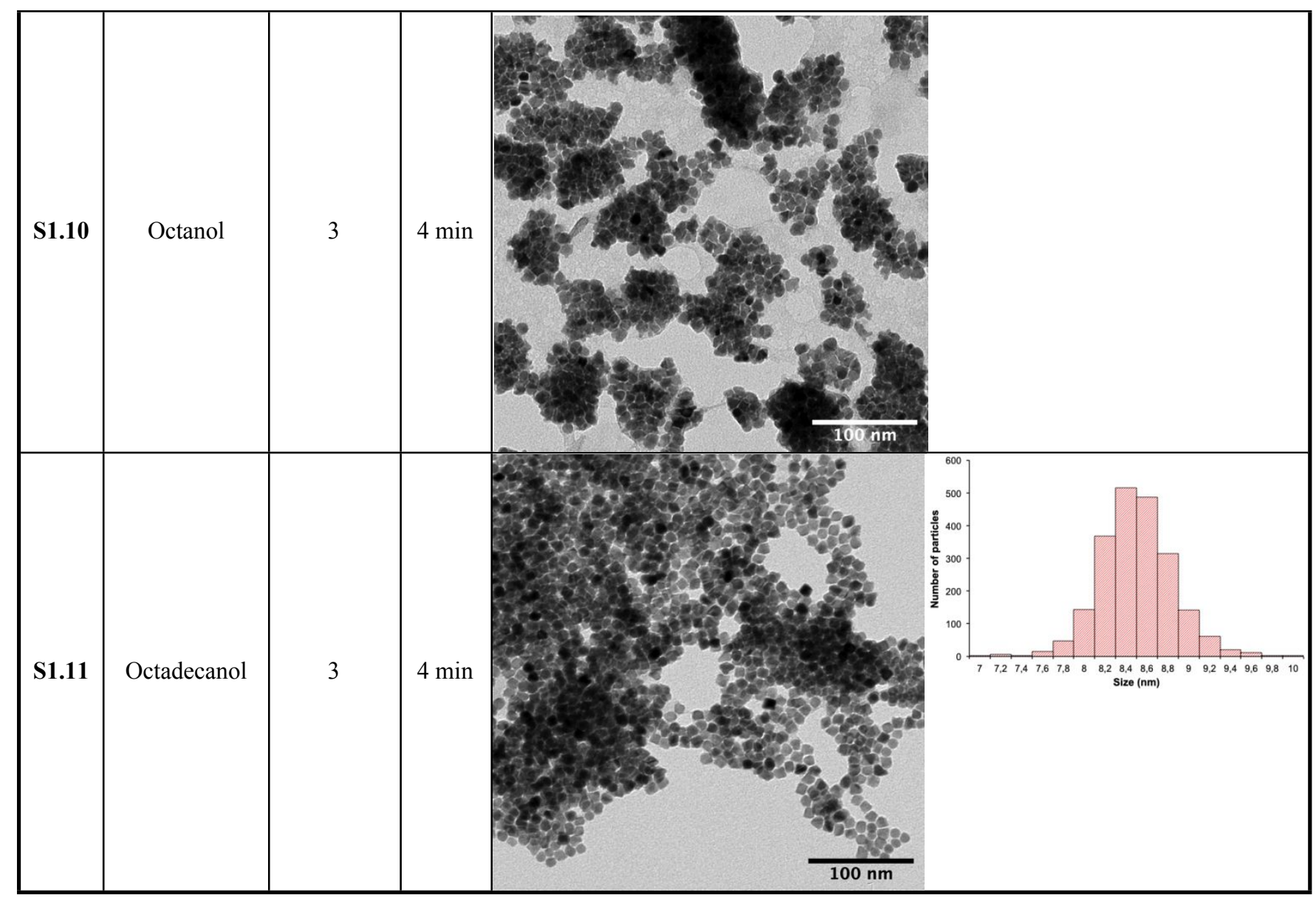




\section{High Resolution TEM characterization of the synthesis Cobalt NPs from $\left[\mathrm{CICo}\left(\mathrm{PPh}_{3}\right)_{3}\right]$ precursors stabilized by 3 equivalents of tridecanol}

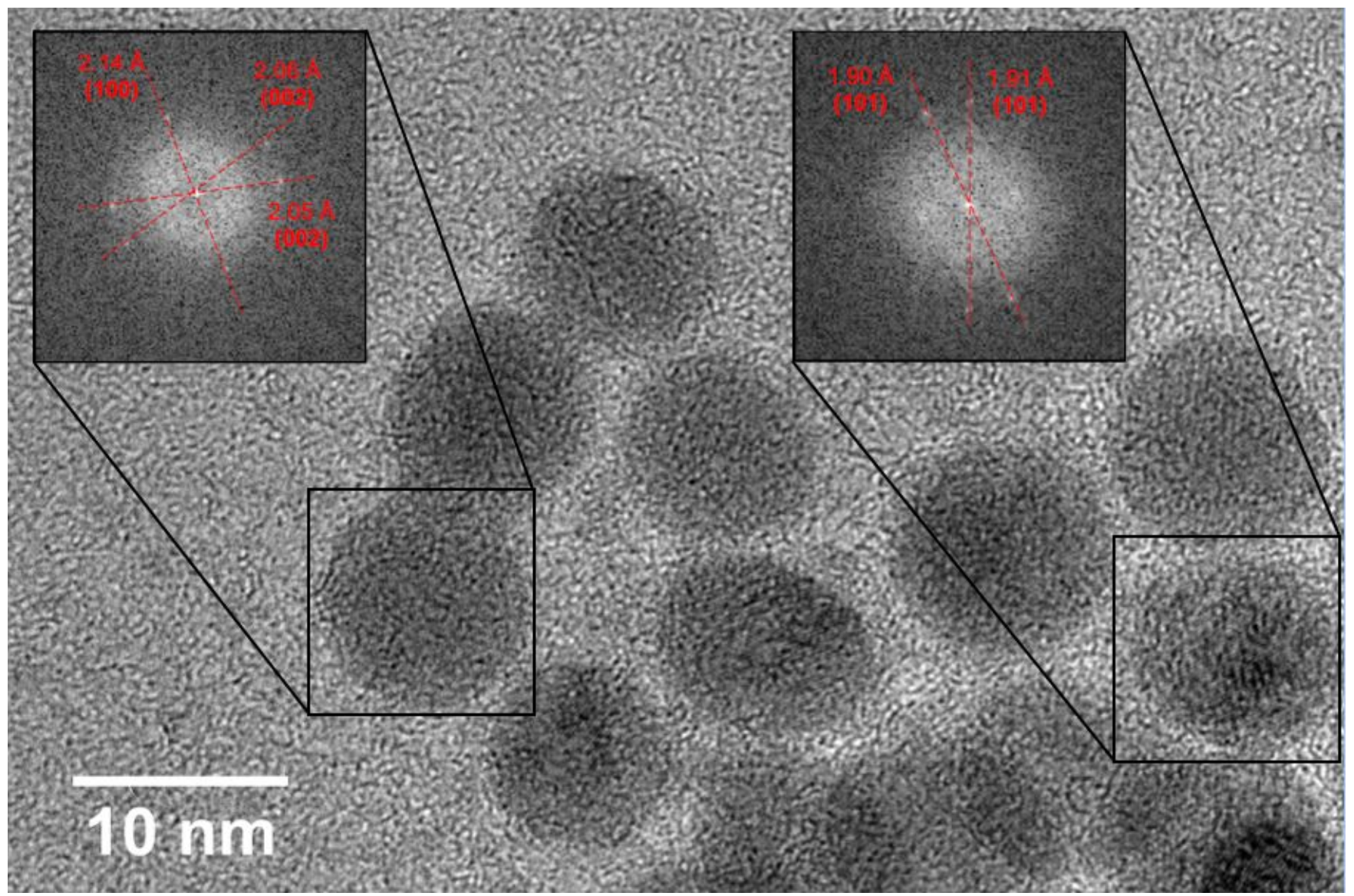

Figure S2. HRTEM of Co nanoparticles capped by tridecanol and interreticular determination in zoom.

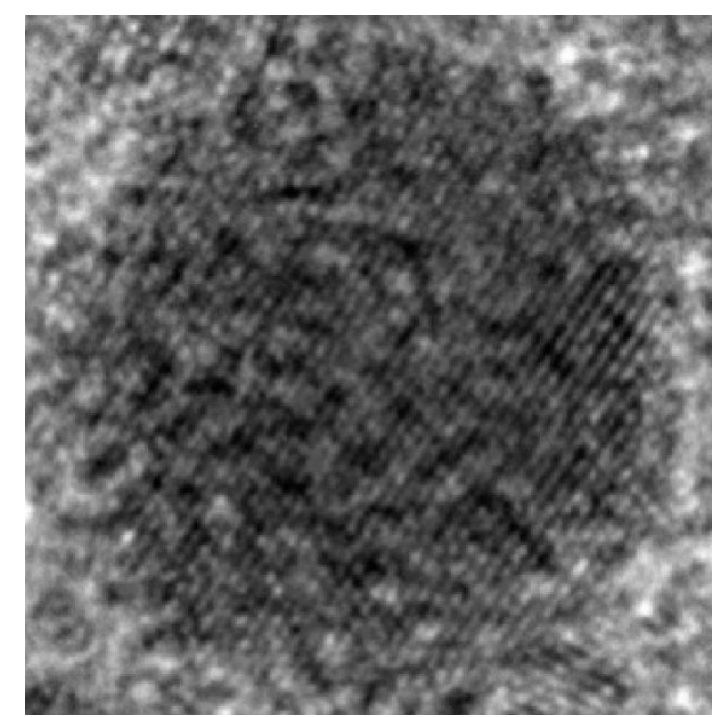

Figure S3. HRTEM zoom on an isolated Co nanoparticles capped by tridecanol. 
Microscopic characterization of the synthesis Cobalt NPs from $\left[\mathrm{XCo}\left(\mathrm{PPh}_{3}\right)_{3}\right]$ precursors stabilized by 3 equivalents of tridecanol

Table S4. TEM pictures and histogram of the synthesis of nanoparticles by $\left[\mathrm{XCo}\left(\mathrm{PPh}_{3}\right)_{3}\right]$.

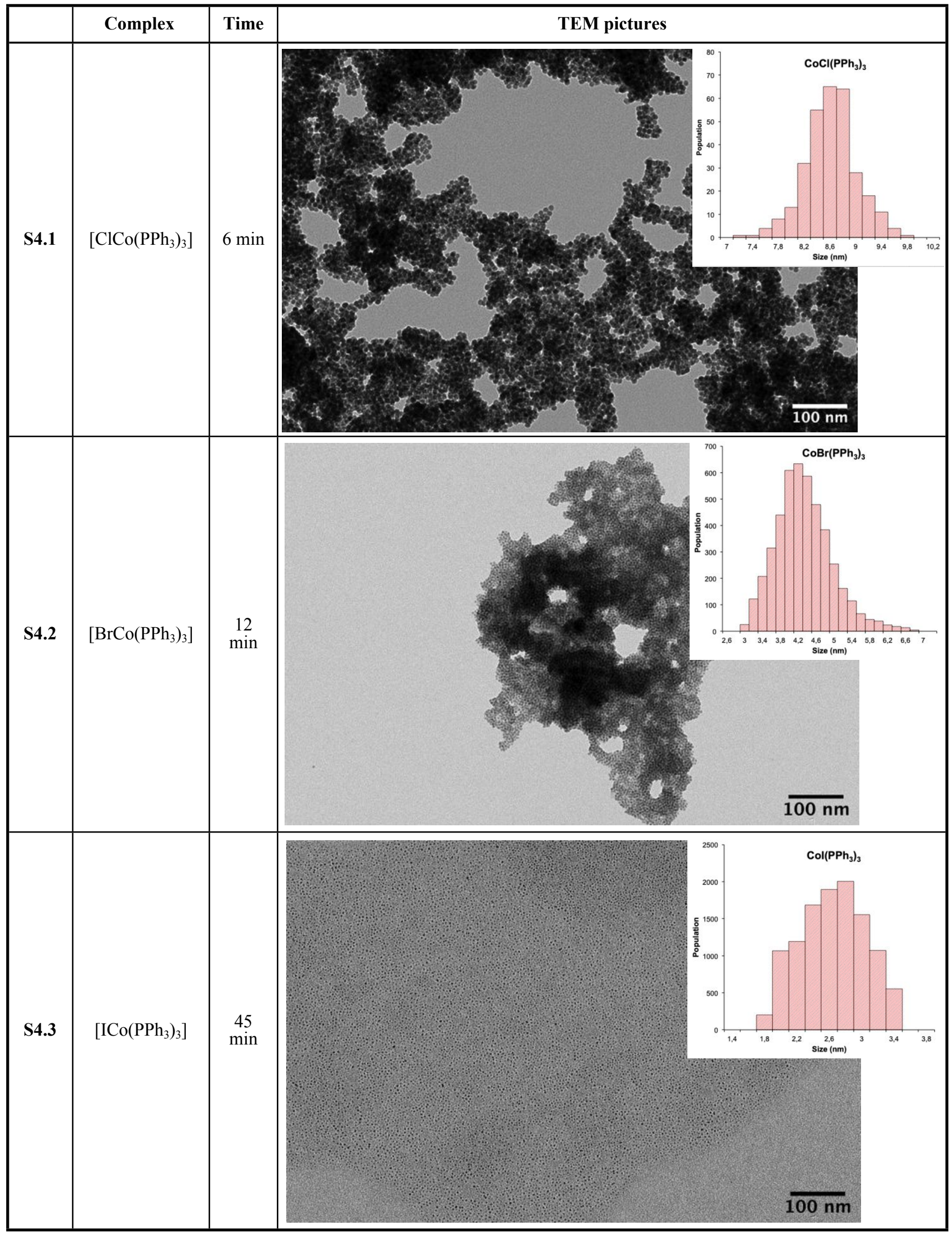




\section{Characterization of NPs coordination sphere}

\section{1- Cobalt NPs capped by tridecanol}

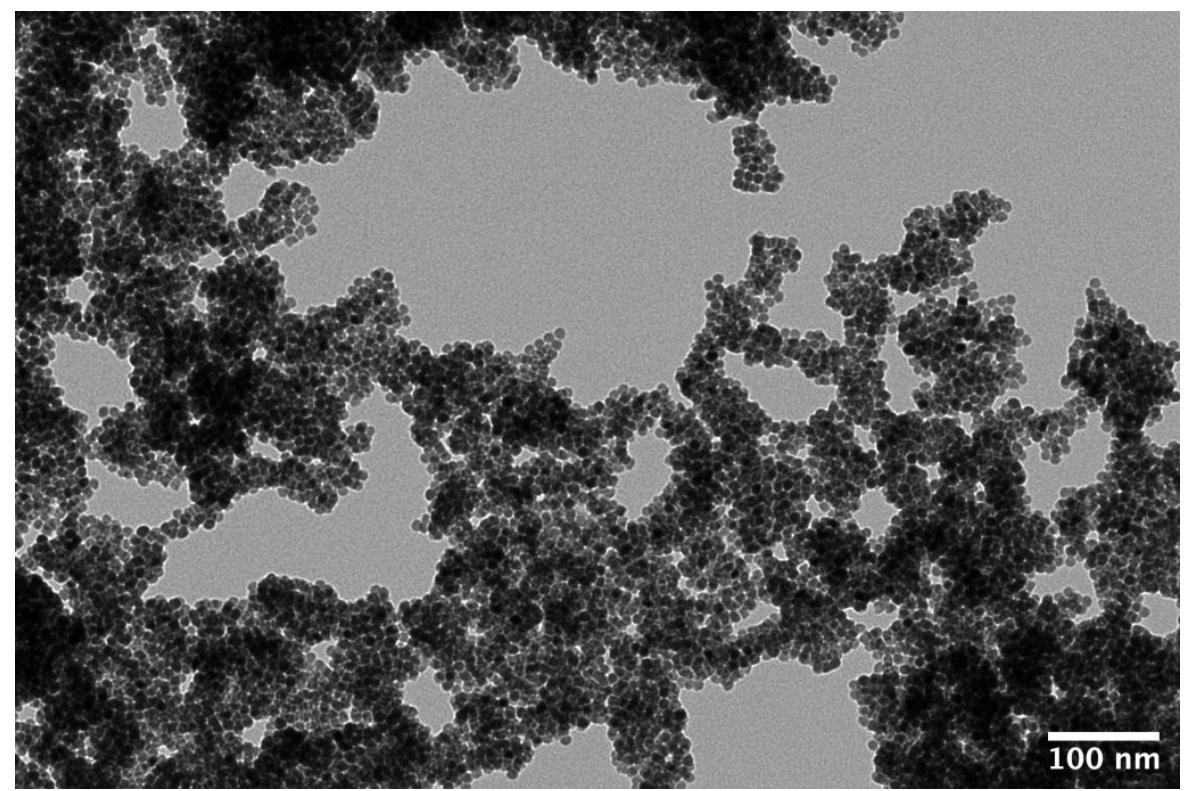

Figure S5. TEM of Co nanoparticles capped by tridecanol.

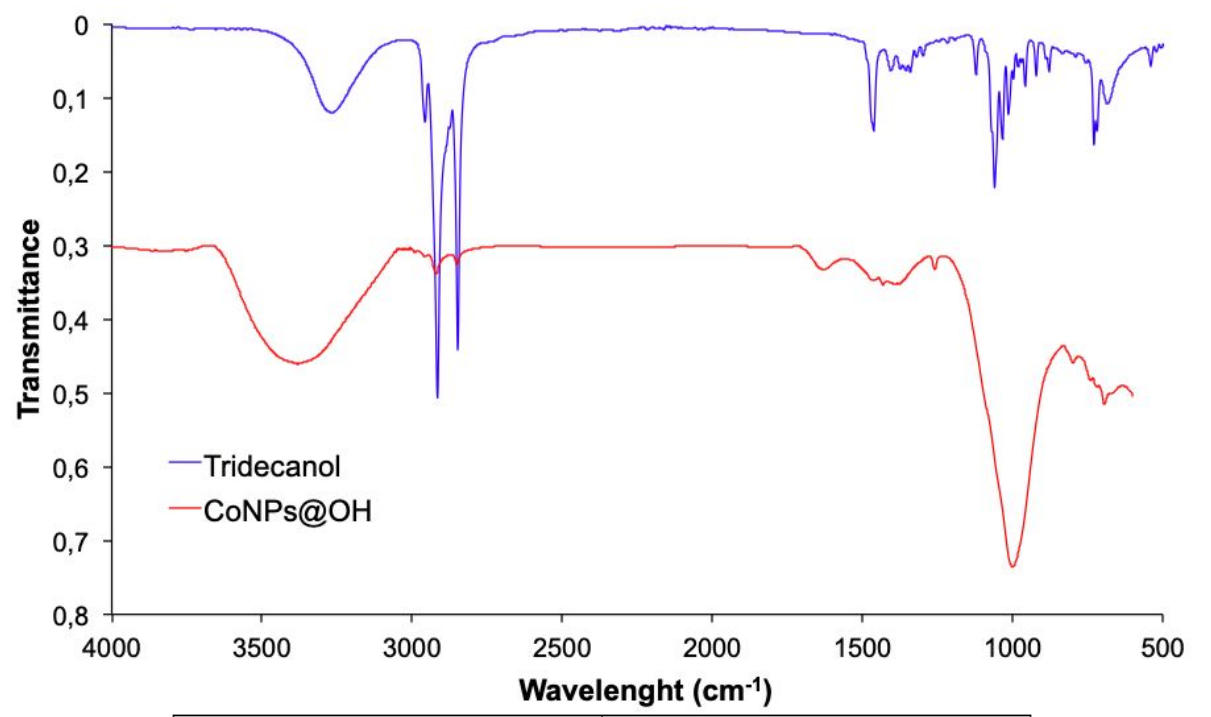

\begin{tabular}{|c|c|}
\hline Peak $\left(\mathbf{c m}^{-1}\right)$ & Attribution \\
\hline 3410 & $\mathrm{v}(\mathrm{O}-\mathrm{H})$ \\
\hline 2926 & $\mathrm{v}\left(\mathrm{C}_{\mathrm{sp} 3}-\mathrm{H}\right)$ \\
\hline 2856 & $\mathrm{v}\left(\mathrm{C}_{\mathrm{sp} 3}-\mathrm{H}\right)$ \\
\hline 1010 & $\partial(\mathrm{O}-\mathrm{H})$ \\
\hline
\end{tabular}

Figure S6. IR of Co nanoparticles capped by tridecanol and table of attribution. 


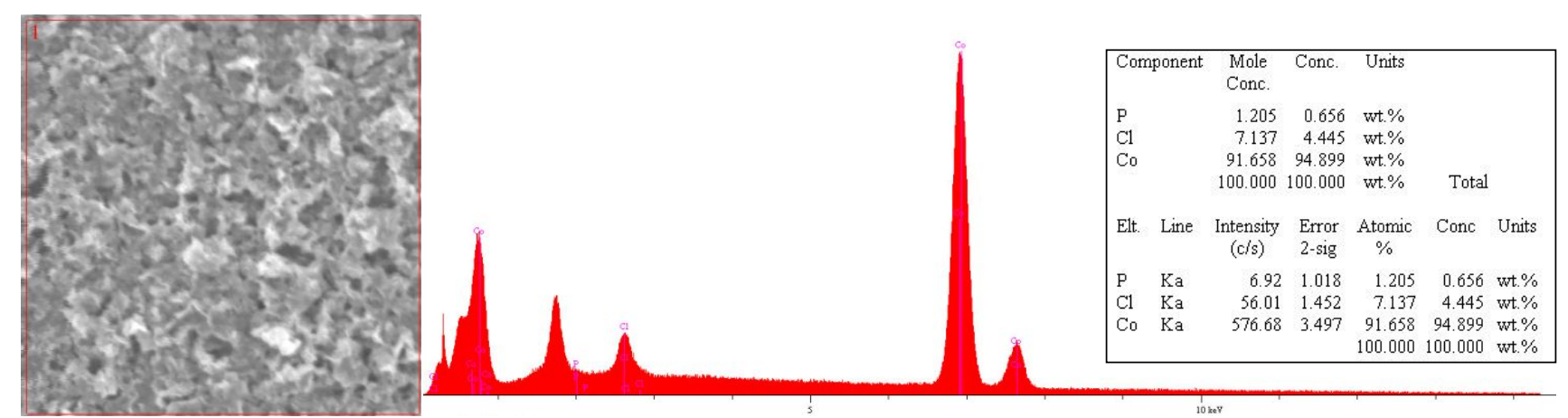

Figure S7. SEM-EDX of Co nanoparticles capped by tridecanol.

\section{2- Cobalt NPs capped by oleic acid}

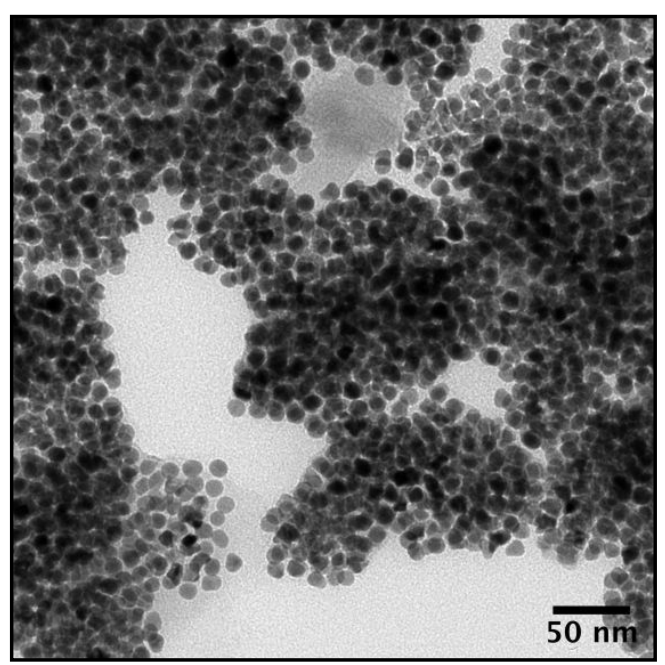

Figure S8. TEM of Co nanoparticles after ligand exchange by oleic acid (OA)

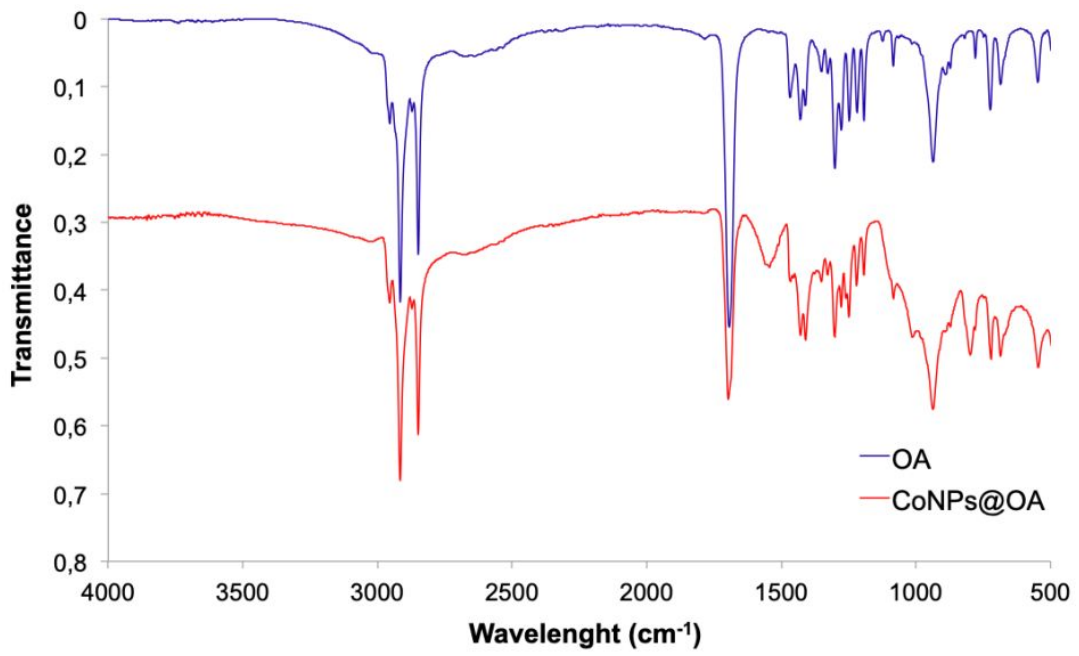

\begin{tabular}{|c|c|c|c|}
\hline Peak $\left(\mathbf{c m}^{-1}\right)$ & Attribution & Peak $\left.\mathbf{c m}^{-1}\right)$ & Attribution \\
\hline 2955 & $\mathrm{v}\left(\mathrm{C}_{\mathrm{sp} 3}-\mathrm{H}\right)$ & 1561 & $\begin{array}{c}\mathrm{v}(\mathrm{C}=\mathrm{O}) \text { coordinated } \\
\text { carbonyl group }\end{array}$ \\
\hline 2916 & $\mathrm{v}\left(\mathrm{C}_{\mathrm{sp} 3}-\mathrm{H}\right)$ & 1410 & $\partial(\mathrm{O}-\mathrm{H})$ \\
\hline 2887 & $\mathrm{v}\left(\mathrm{C}_{\mathrm{sp} 3}-\mathrm{H}\right)$ & 1320 & $\mathrm{v}(\mathrm{C}-\mathrm{O})$ \\
\hline
\end{tabular}




\begin{tabular}{|c|c|c|c|}
\hline 2848 & $\mathrm{v}\left(\mathrm{C}_{\mathrm{sp} 3}-\mathrm{H}\right)$ & 933 & $\partial(\mathrm{O}-\mathrm{H})$ \\
\hline 1707 & $\begin{array}{c}\mathrm{v}(\mathrm{C}=\mathrm{O}) \text { free carbonyl } \\
\text { group }\end{array}$ & & \\
\hline
\end{tabular}

Figure S9. IR of Co nanoparticles after ligand exchange by oleic acid (OA) and attribution

\section{3- Cobalt NPs capped by oleylamine}

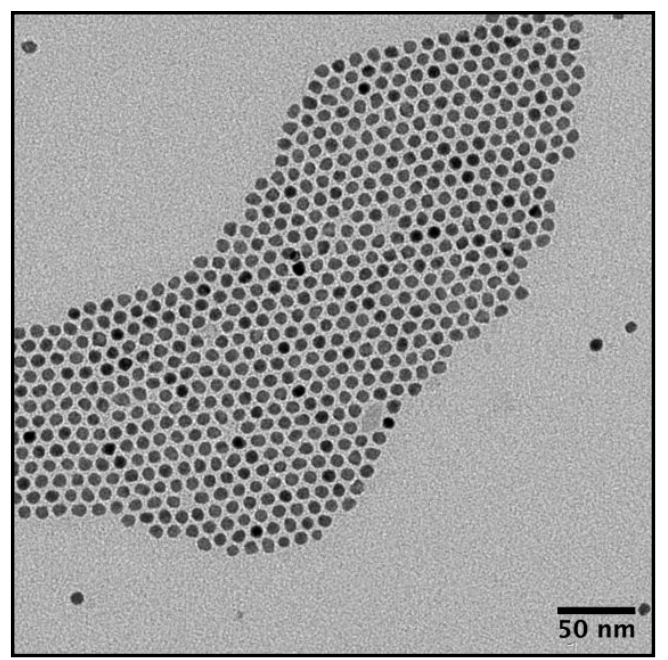

Figure S10. TEM of Co nanoparticles after ligand exchange by oleyamine (OAm)

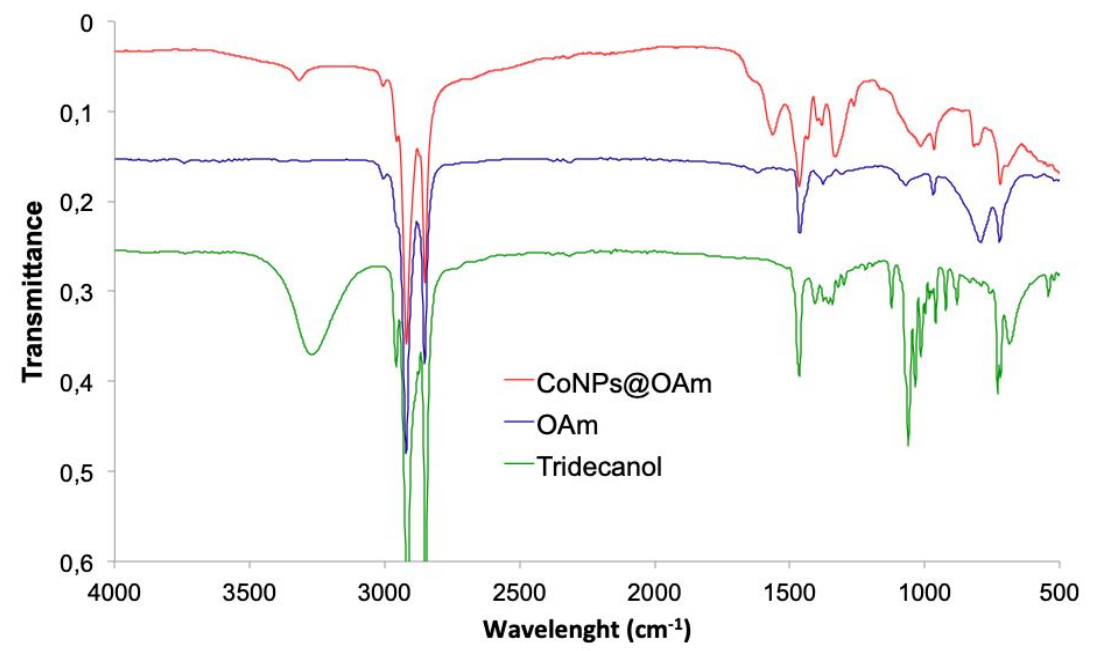

\begin{tabular}{|c|c|c|c|}
\hline Peak $\left(\mathbf{c m}^{-1}\right)$ & Attribution & Peak (cm-1) & Attribution \\
\hline 3332 & $\mathrm{v}(\mathrm{N}-\mathrm{H})$ of primary amine & 1570 & $\partial(\mathrm{N}-\mathrm{H})$ of primary amine \\
\hline 3013 & $\mathrm{v}\left(\mathrm{C}_{\mathrm{sp2}}-\mathrm{C}_{\mathrm{sp2} 2}\right)$ & 1020 & $\mathrm{v}(\mathrm{C}-\mathrm{N})$ \\
\hline 2932 & $\mathrm{v}\left(\mathrm{C}_{\mathrm{sp3} 3}-\mathrm{H}\right)$ & 810 & $\gamma(\mathrm{N}-\mathrm{H})$ \\
\hline 2843 & $\mathrm{v}\left(\mathrm{C}_{\mathrm{sp3} 3}-\mathrm{H}\right)$ & & \\
\hline
\end{tabular}

Figure S11. IR of Co nanoparticles after ligand exchange by oleyamine (OAm) and attribution 


\section{4- Cobalt NPs capped by trioctylphosphine}

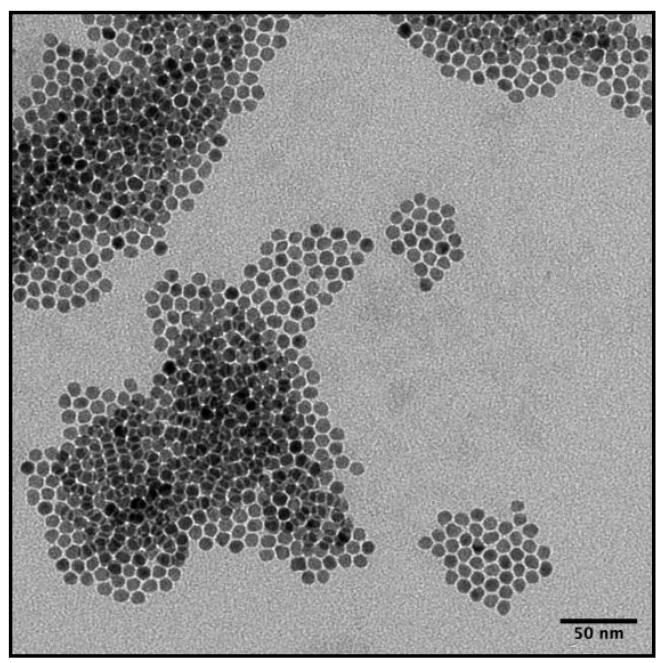

Figure S12. TEM of Co nanoparticles after ligand exchange by trioctylphosphine (TOP)

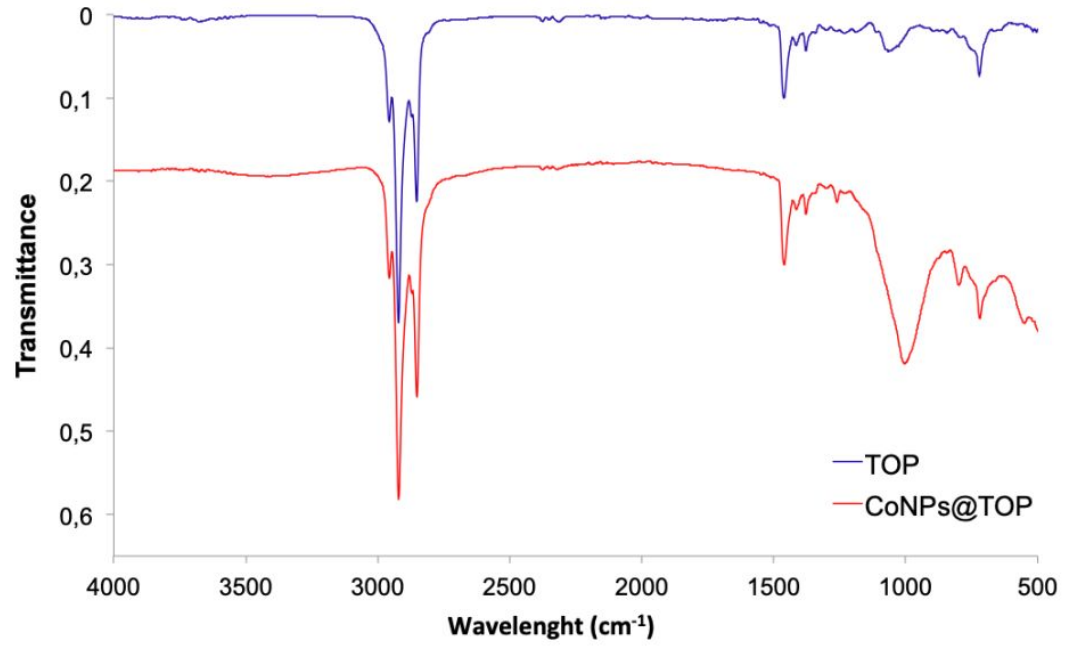

\begin{tabular}{|c|c|c|c|}
\hline Peak (cm $\left.{ }^{-1}\right)$ & Attribution & Peak (cm-1) & Attribution \\
\hline 3410 & $\mathrm{v}(\mathrm{O}-\mathrm{H})$ & 1456 & $\mathrm{v}\left(\mathrm{CH}_{2}\right)$ \\
\hline 2939 & $\mathrm{v}\left(\mathrm{C}_{\mathrm{sp} 3}-\mathrm{H}\right)$ & 1010 & $\partial(\mathrm{O}-\mathrm{H})$ \\
\hline 2922 & $\mathrm{v}\left(\mathrm{C}_{\mathrm{sp3} 3}-\mathrm{H}\right)$ & 714 & $\gamma\left(\mathrm{CH}_{2}\right)$ \\
\hline 2853 & $\mathrm{v}\left(\mathrm{C}_{\mathrm{sp3} 3}-\mathrm{H}\right)$ & & \\
\hline
\end{tabular}

Figure S13. IR of Co nanoparticles after ligand exchange by trioctylphosphine (TOP) and attribution 


\section{5- Cobalt NPs capped by trioctylphosphine oxide}

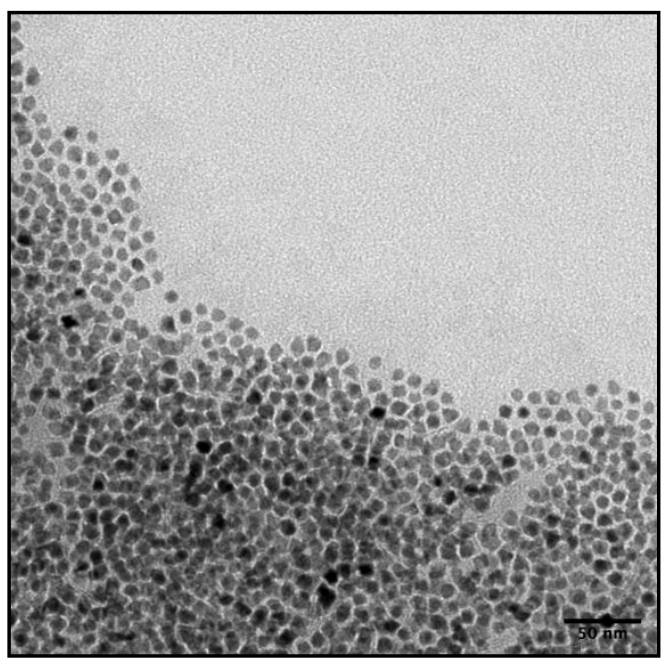

Figure S14. TEM of Co nanoparticles after ligand exchange by trioctylphosphine oxide (TOPO) ${ }^{1}$

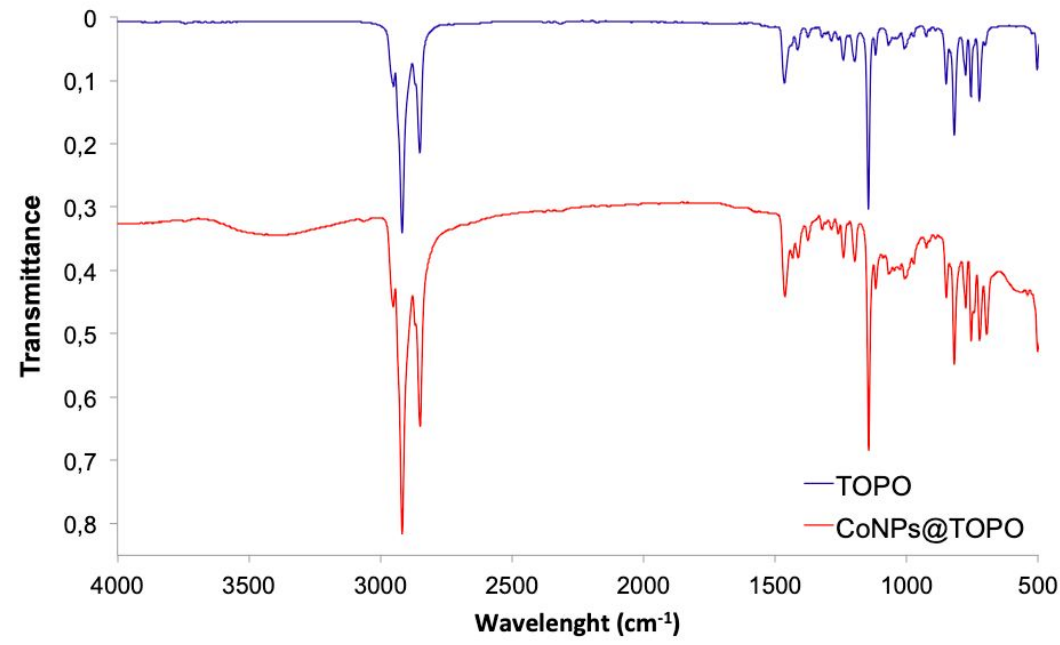

\begin{tabular}{|c|c|c|c|}
\hline Peak $\left.\mathbf{( c m}^{-1}\right)$ & Attribution & Peak (cm $\left.{ }^{-1}\right)$ & Attribution \\
\hline 3410 & $\mathrm{v}(\mathrm{O}-\mathrm{H})$ & 2851 & $\mathrm{v}\left(\mathrm{C}_{\mathrm{sp} 3}-\mathrm{H}\right)$ \\
\hline 2955 & $\mathrm{v}\left(\mathrm{C}_{\mathrm{sp} 3}-\mathrm{H}\right)$ & 1466 & $\mathrm{v}\left(\mathrm{CH}_{2}\right)$ \\
\hline 2918 & $\mathrm{v}\left(\mathrm{C}_{\mathrm{sp} 3}-\mathrm{H}\right)$ & 1144 & $\partial(\mathrm{P}=\mathrm{O})$ \\
\hline
\end{tabular}

Figure S15. IR of Co nanoparticles after ligand exchange by trioctylphosphine oxide (TOPO) and attribution.

${ }^{1} \mathrm{~J}$. Ma Preparation and characterization of $\mathrm{ZrO} 2$ nanoparticles capped by trioctylphosphine oxide (TOPO), 2011, Journal of Wuhan University of Technology-Materials Science Edition, vol. 26, no. 4, pp. 611-614. 


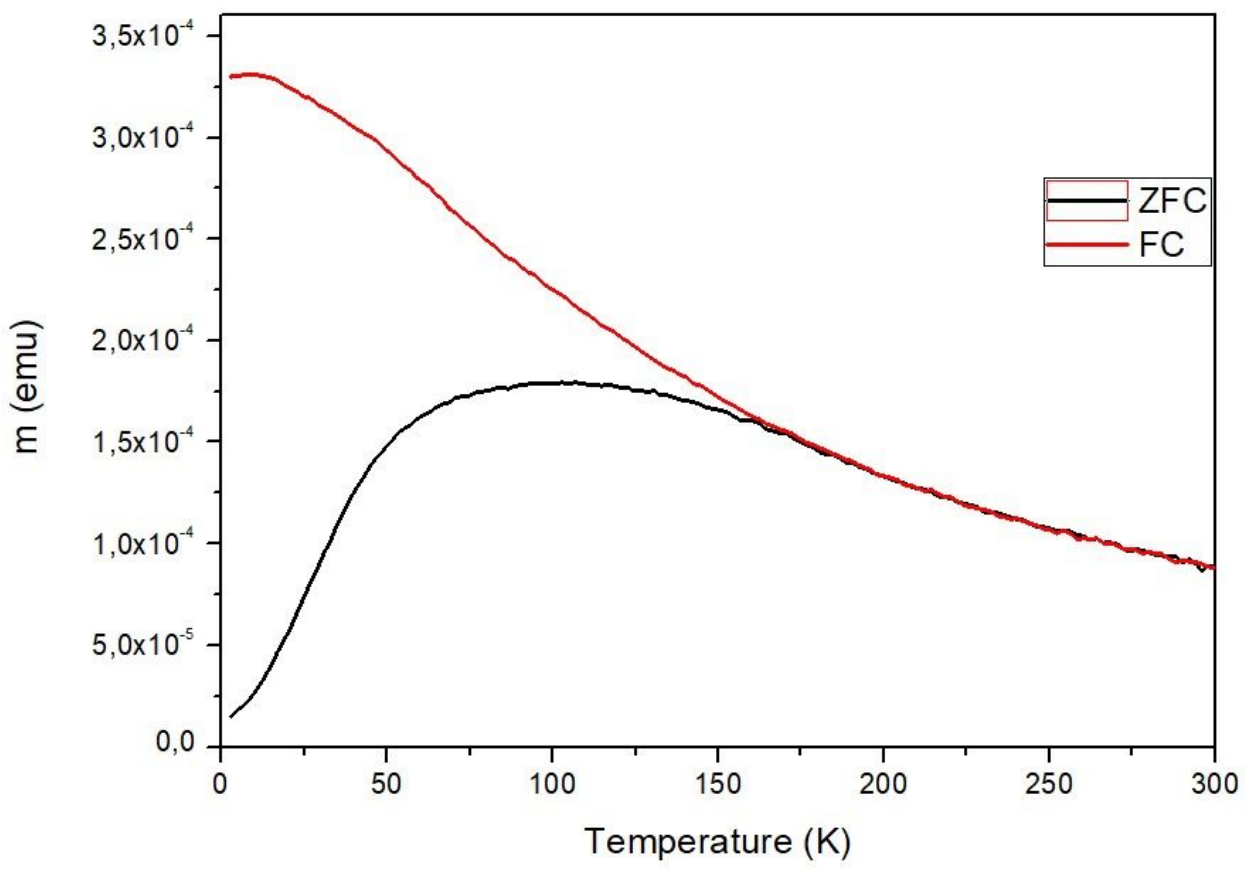

Figure S16. ZFC/FC behaviour of NPs from $\left[\mathrm{BrCo}\left(\mathrm{PPh}_{3}\right)_{3}\right]$

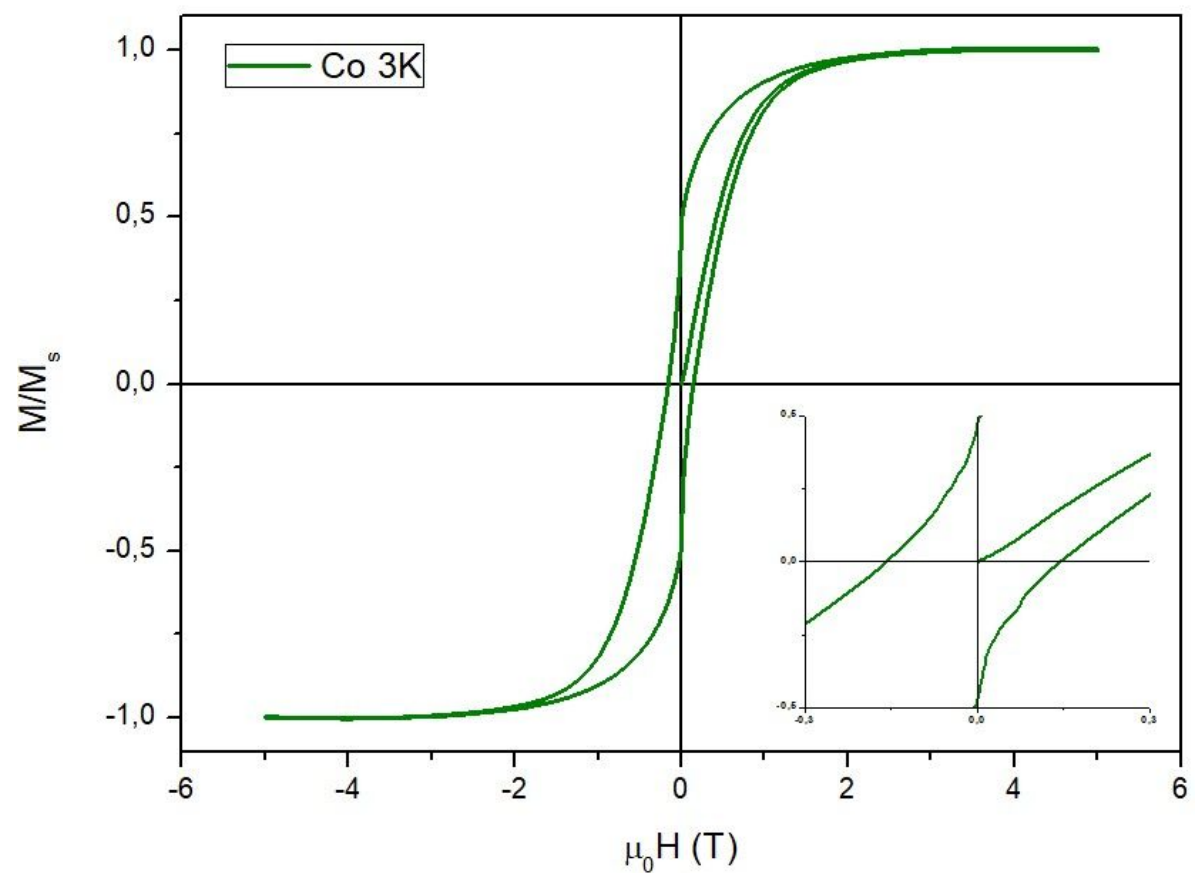

Figure S17. Magnetization cycle of NPs from $\left[\mathrm{BrCo}\left(\mathrm{PPh}_{3}\right)_{3}\right]$ 


\section{Catalytic products characterization}

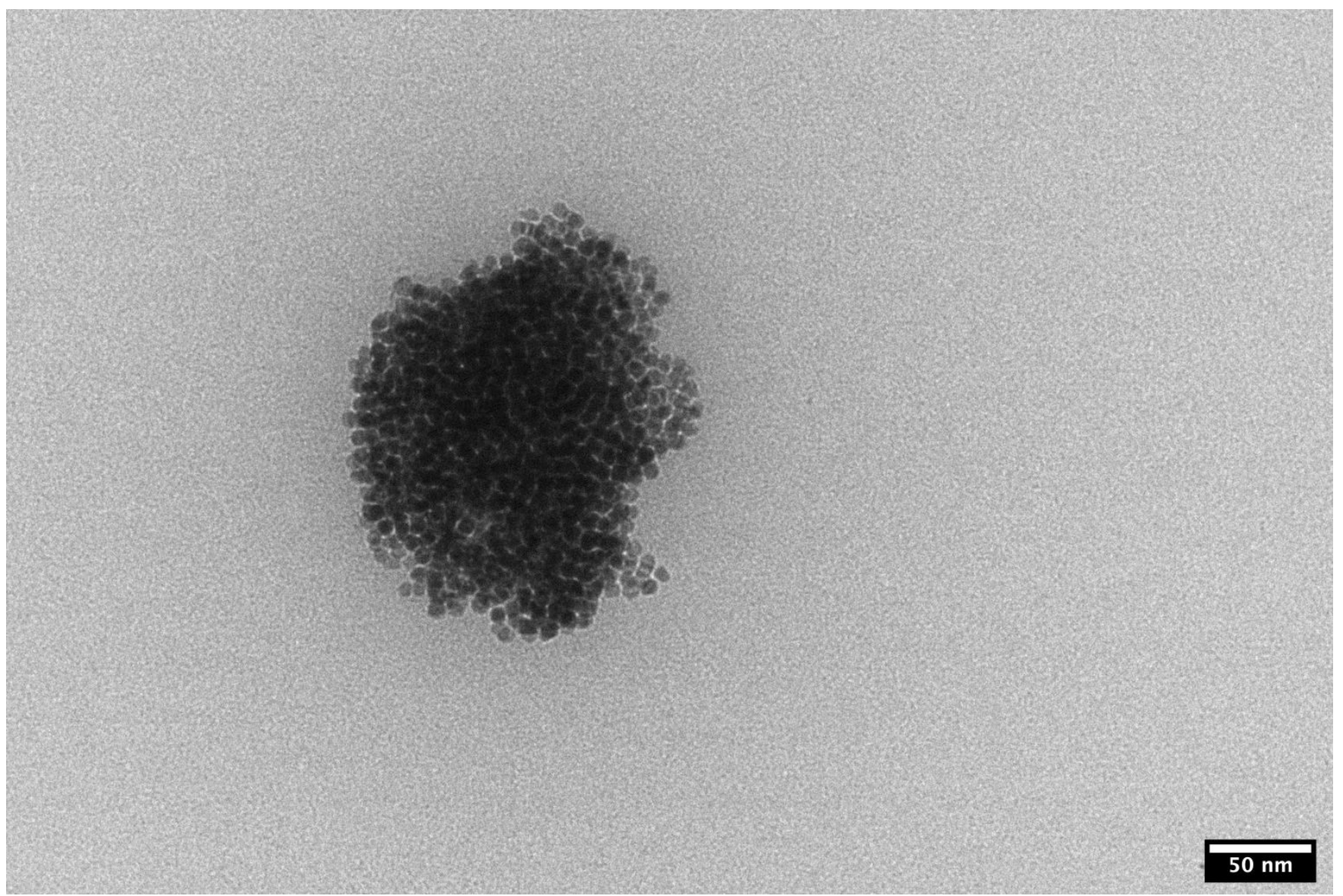

Figure S18. TEM picture of Co NPs after one catalytic test.

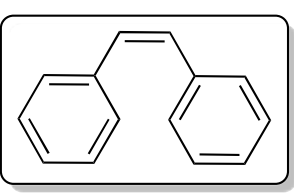

(Z)-Stilbene: Colorless oil. The proton NMR matches with the commercially available compound. ${ }^{1} \mathrm{H}$ NMR $\left(400 \mathrm{MHz}, \mathrm{CDCl}_{3}\right): \delta=7.14-7.31(\mathrm{~m}, 10 \mathrm{H}), 6.60$ (s, 2H) ppm.

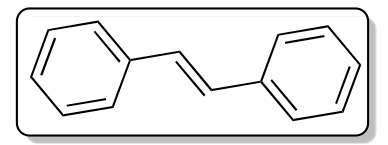

(E)-Stilbene: White solid. The proton NMR matches with the commercially available compound. ${ }^{1} \mathrm{H}$ NMR $\left(400 \mathrm{MHz}, \mathrm{CDCl}_{3}\right): \delta=7.53-7.54(\mathrm{~d}, \mathrm{~J}=7.2$ $\mathrm{Hz}, 4 \mathrm{H}), 7.36-7.39$ (t, J = 7.8 Hz, 4H), $7.26-7.29$ (t, J = 7.8 Hz, 2H), 7.13 (s,

2H) $\mathrm{ppm}$.

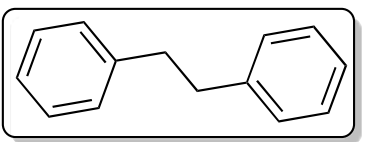

1,2-diphenylethane: Colorless solid. The proton NMR matches with the commercially available compound. ${ }^{1} \mathrm{H}$ NMR $\left(400 \mathrm{MHz}, \mathrm{CDCl}_{3}\right): \delta=7.21-$ 7.45 (m, 10H), 2.85 (s, 1H) ppm. 

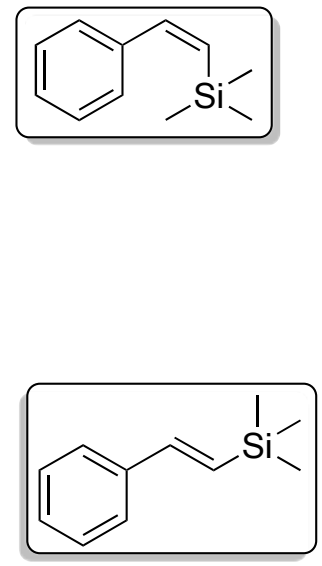

(E)-Trimethyl(2-phenylethenyl)silane ${ }^{3}$ : Yellow oil. ${ }^{1} \mathrm{H}$ NMR $\left(400 \mathrm{MHz}, \mathrm{CDCl}_{3}\right)$ : $\delta=7.27-7.48(\mathrm{~m}, 5 \mathrm{H}), 6.91(\mathrm{~d}, \mathrm{~J}=19.0 \mathrm{~Hz}, 1 \mathrm{H}), 6.51(\mathrm{~d}, \mathrm{~J}=19.0 \mathrm{~Hz}, 1 \mathrm{H}), 0.19$ $(\mathrm{s}, 9 \mathrm{H}) \mathrm{ppm}$.

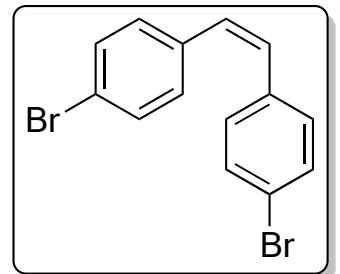

(Z)-4,4'-dibromostilbene': White solid. ${ }^{1} \mathrm{H}$ NMR (400 MHz, $\left.\mathrm{CDCl}_{3}\right): \delta=7.37$ (dd, J = 8.8, 2.2 Hz, 4H), 7.09 (dd, J = 8.8 Hz, 2.2 Hz, 4H), 6.55 (s, 2H) ppm.

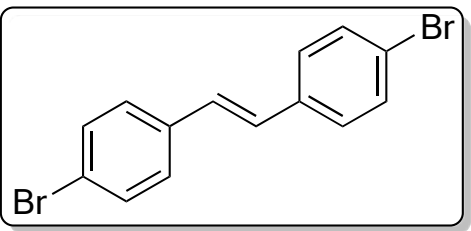

(E)-4,4'-dibromostilbene ${ }^{5}$ : White solid. ${ }^{1} \mathrm{H}$ NMR (400 MHz, $\left.\mathrm{CDCl}_{3}\right)$ : $\delta$ $=7.49(\mathrm{~d}, \mathrm{~J}=8.7 \mathrm{~Hz}, 4 \mathrm{H}), 7.37(\mathrm{~d}, \mathrm{~J}=8.7 \mathrm{~Hz}, 4 \mathrm{H}), 7.01(\mathrm{~s}, 2 \mathrm{H}) \mathrm{ppm}$.

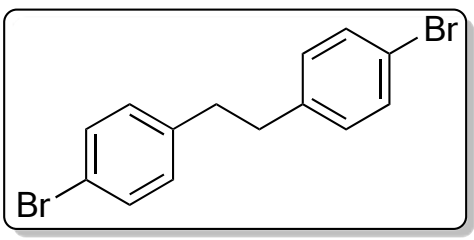

1,2-Bis(4-bromopheny1)ethane: White solid. ${ }^{1} \mathrm{H}$ NMR $(400 \mathrm{MHz}$, $\left.\mathrm{CDCl}_{3}\right): \delta=7.41(\mathrm{~d}, \mathrm{~J}=8.7 \mathrm{~Hz}, 4 \mathrm{H}), 7.05(\mathrm{~d}, \mathrm{~J}=8.7 \mathrm{~Hz}, 4 \mathrm{H}), 2.84(\mathrm{~s}$, 4H) ppm.

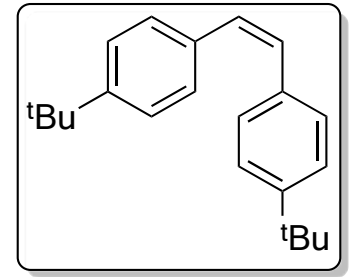

(Z)-1,1'-(1,2-ethenediyl)bis(4-butyl)benzene': White solid. ${ }^{1} \mathrm{H}$ NMR (400 $\left.\mathrm{MHz}, \mathrm{CDCl}_{3}\right): \delta=7.35(\mathrm{~d}, \mathrm{~J}=8.2 \mathrm{~Hz}, 4 \mathrm{H}), 7.02(\mathrm{~d}, \mathrm{~J}=8.2 \mathrm{~Hz}, 4 \mathrm{H}), 6.67(\mathrm{~s}$, 2H), $2.54(\mathrm{t}, \mathrm{J}=7.3 \mathrm{~Hz}, 4 \mathrm{H}), 1.41-1.52(\mathrm{~m}, 4 \mathrm{H}), 1.31-1.39$ (m, 4H), 0.94 (t, J $=7.3 \mathrm{~Hz}, 6 \mathrm{H})$.

\footnotetext{
${ }^{2}$ Nishihara, Y.; Saito, D.; Tanemura, K.; Noyori, S.; Takagi, K. Org. Lett. 2009, 11, 3546-3549.

3 Thiot, C.; Mioskowski, C.; Wagner, A. Eur. J. Org. Chem. 2009, 3219-3227.

${ }^{4}$ Bosanac, T.; Wilcox, C. S. Org. Lett. 2004, 6, 2321-2324.

5 Jeong, N. and coll. Angew. Chem. Int. Ed. 2006, 45, 8134-8138.

${ }^{6}$ Liu, J.; Li, B. Synth. Commun. 2007, 37, 3273-3278.

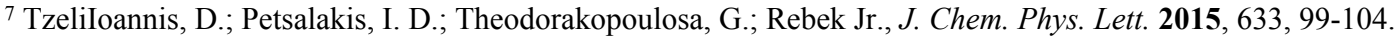



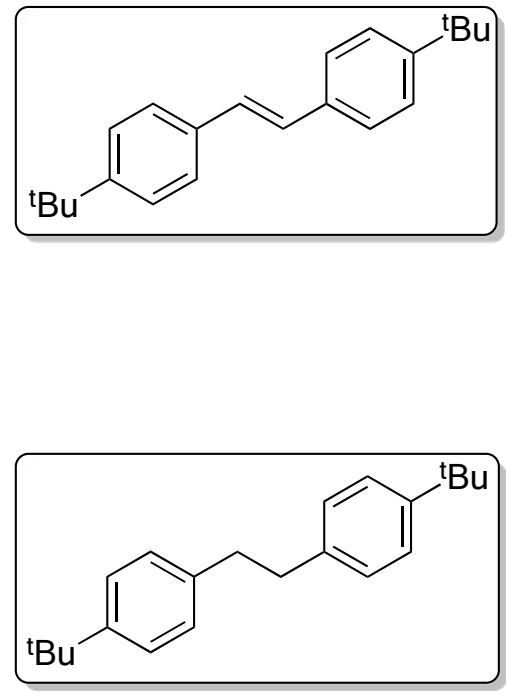

(E)-1,1'-(1,2-ethenediyl)bis(4-butyl)benzene ${ }^{8}$ : White solid. ${ }^{1} \mathrm{H}$ NMR $\left(400 \mathrm{MHz}, \mathrm{CDCl}_{3}\right): \delta=7.46(\mathrm{~d}, \mathrm{~J}=8.1 \mathrm{~Hz}, 4 \mathrm{H}), 7.11(\mathrm{~d}, \mathrm{~J}=8.0 \mathrm{~Hz}$, 4H), 7.08 (s, 2H), 2.58 (t, J = 7.6 Hz, 4H), 1.55 - 1.63 (m, 4H), 1.37 $1.45(\mathrm{~m}, 4 \mathrm{H}), 0.98(\mathrm{t}, \mathrm{J}=7.3 \mathrm{~Hz}, 6 \mathrm{H})$.

4,4'-dibutyldiphenylethane': White solid. ${ }^{1} \mathrm{H}$ NMR $(400 \mathrm{MHz}$, $\left.\mathrm{CDCl}_{3}\right): \delta=7.36(\mathrm{~d}, \mathrm{~J}=8.2 \mathrm{~Hz}, 4 \mathrm{H}), 7.02(\mathrm{~d}, \mathrm{~J}=8.2 \mathrm{~Hz}, 4 \mathrm{H}), 2.86(\mathrm{~s}$, $4 \mathrm{H}), 2.54(\mathrm{t}, \mathrm{J}=7.5 \mathrm{~Hz}, 4 \mathrm{H}), 1.46-1.55(\mathrm{~m}, 4 \mathrm{H}), 1.34$ - $1.41(\mathrm{~m}, 4 \mathrm{H})$, $0.96(\mathrm{t}, \mathrm{J}=7.4 \mathrm{~Hz}, 6 \mathrm{H})$.

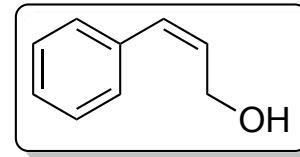

(Z)-Cinnamyl alcohol ${ }^{10}$ : Colorless solid. ${ }^{1} \mathrm{H}$ NMR (400 MHz, $\mathrm{CDCl}_{3}$ ): $\delta=7.35$ (t, $\mathrm{J}=7.4 \mathrm{~Hz}, 2 \mathrm{H}), 7.26(\mathrm{dd}, \mathrm{J}=8.7 \mathrm{~Hz}, 5.8 \mathrm{~Hz}, 1 \mathrm{H}), 7.21(\mathrm{~d}, \mathrm{~J}=7.4 \mathrm{~Hz}, 2 \mathrm{H}), 6.58$ $(\mathrm{d}, \mathrm{J}=11.7 \mathrm{~Hz}, 1 \mathrm{H}), 5.96-5.81(\mathrm{~m}, 1 \mathrm{H}), 4.45(\mathrm{~d}, \mathrm{~J}=6.4 \mathrm{~Hz}, 2 \mathrm{H}), 1.53(\mathrm{~s}, 1 \mathrm{H})$ ppm.

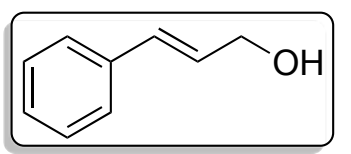

(E)-Cinnamyl alcohol ${ }^{11}$ : Colorless solid. ${ }^{1} \mathrm{H}$ NMR (400 MHz, $\mathrm{CDCl}_{3}$ ): $\delta=7.80$ $(\mathrm{d}, \mathrm{J}=15.5 \mathrm{~Hz}, 2 \mathrm{H}), 7.50-7.60(\mathrm{~m}, 2 \mathrm{H}), 7.36-7.44(\mathrm{~m}, 3 \mathrm{H}), 6.46$ (d, J = 15.5 $\mathrm{Hz}, 2 \mathrm{H}), 1.53$ (s, 1H) ppm.

Benzenepropanol: Colorless solid. The proton NMR matches with the commercially available compound. ${ }^{1} \mathrm{H} \mathrm{NMR}\left(400 \mathrm{MHz}, \mathrm{CDCl}_{3}\right): \delta=7.15$ - 7.27 (m, 5H), $3.62(\mathrm{t}, \mathrm{J}=6.3 \mathrm{~Hz}, 2 \mathrm{H}), 2.65(\mathrm{t}, \mathrm{J}=7.8 \mathrm{~Hz}, 2 \mathrm{H}), 1.81 \mathrm{R} 1.89(\mathrm{~m}, 2 \mathrm{H})$, $1.50(\mathrm{~s}, 1 \mathrm{H}) \mathrm{ppm}$.

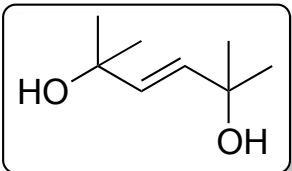

(E)-2,5-dimethyl-hex-3-ene-2,5-diol' ${ }^{\mathbf{1 2}}$ : colorless oil ${ }^{1} \mathrm{H}$ NMR (400 MHz, $\left.\mathrm{CDCl}_{3}\right)$ : $=5.80(\mathrm{~s}, 2 \mathrm{H}), 1.33(\mathrm{~s}, 12 \mathrm{H}) \mathrm{ppm}$.

\footnotetext{
${ }^{8}$ Zhang, Y.; Ye, W.; Leng, X.; He, Y.; Zhang, H.; Xiao, X. Tetrahedron Lett. 2016, 57, 4203-4206.

${ }^{9}$ Fujio, M. Kobunshi Kagaku 1947, 4, 15-18.

${ }^{10}$ Motte, L.; Petit, C.; Boulanger, L.; Lixon, P.; Pileni, M. P. Langmuir 1992, 8, 1049-1053.

11 Shibuya, M.; Sato, T.; Tomizawa, M.; Iwabuchi, Y. Chem. Commun. 2009, 1739-1741.

12 Tan, H.; Espenson, J. H. Inorg. Chem. 1998, 37, 467-472.
} 


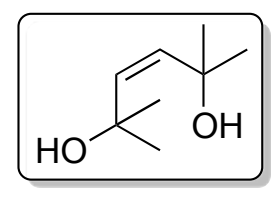

(Z)-2,5-dimethyl-hex-3-ene-2,5-diol ${ }^{\mathbf{1 3}}$ : colorless oil ${ }^{1} \mathrm{H}$ NMR (400 $\left.\mathrm{MHz}, \mathrm{CDCl}_{3}\right)$ : $=5.35(\mathrm{~s}, 2 \mathrm{H}), 1.40(\mathrm{~s}, 12 \mathrm{H}) \mathrm{ppm}$.

(Z)-4-phenylbut-3-en-2-ol ${ }^{14}$ : White solid. ${ }^{1} \mathrm{H}$ NMR (400 MHz, $\left.\mathrm{CDCl}_{3}\right): \delta=7.35$ - 7.4 (m, 2H), 7.2 - 7.3 (m, 3H), 6.5 (d, J = 11.6 Hz, 1H), 5.7 (dd, J = 11.6 Hz, 9.1 Hz, 1H), 4.85 (m, 1H), 1.7 (br, 1H), 1.4 (d, J = 6.3 Hz, 3H) ppm.

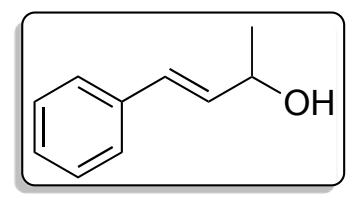

(E)-4-phenylbut-3-en-2-ol ${ }^{15}$ : Colorless oil. ${ }^{1} \mathrm{H}$ NMR (400 MHz, $\mathrm{CDCl}_{3}$ ): $\square=$ 7.44 - 7.40 (m, 2H), 7.35 - 7.38 (m, 2H), $7.28(\mathrm{~m}, 1 \mathrm{H}), 6.58(\mathrm{~d}, \mathrm{~J}=15.6 \mathrm{~Hz}, 1 \mathrm{H})$, 6.27 (dd, J = 15.6 Hz, 6.4 Hz, 1H), 4.49 (dq, J = 6.4 Hz, $6.3 \mathrm{~Hz}, 1 \mathrm{H}$ ), 1.7 (br s, $1 \mathrm{H}), 1.38(\mathrm{~d}, \mathrm{~J}=6.3 \mathrm{~Hz}, 3 \mathrm{H}) \mathrm{ppm}$.

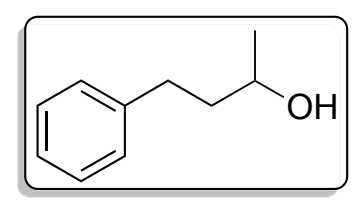

4-phenyl-2-butanol ${ }^{16}$ : Colorless solid. ${ }^{1} \mathrm{H}$ NMR (400 MHz, $\left.\mathrm{CDCl}_{3}\right): \delta=7.22$ $7.35(\mathrm{~m}, 5 \mathrm{H}), 3.82(\mathrm{dd}, \mathrm{J}=12.2 \mathrm{~Hz}, 6.6 \mathrm{~Hz}, 1 \mathrm{H}), 2.65$ Ŕ $2.78(\mathrm{~m}, 2 \mathrm{H}), 1.75$ Ŕ 1.81 (m, 2H), 1.75 (brs, 1H), 1.24 (d, J =6.4 Hz, 3H) ppm.

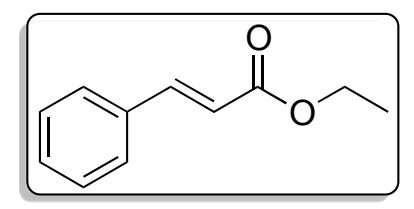

Ethyl-(E)-cinnamate: Colorless solid. ${ }^{1} \mathrm{H}$ NMR (400 $\left.\mathrm{MHz}, \mathrm{CDCl}_{3}\right): \delta=7.70$ $(\mathrm{d}, \mathrm{J}=16 \mathrm{~Hz}, 1 \mathrm{H}), 7.15-7.55(\mathrm{~m}, 5 \mathrm{H}), 6.44(\mathrm{~d}, \mathrm{~J}=16 \mathrm{~Hz}, 1 \mathrm{H}), 4.29(\mathrm{q}, \mathrm{J}=$ $7.2 \mathrm{~Hz}, 2 \mathrm{H}), 1.35$ (m, $3 \mathrm{H}) \mathrm{ppm}$.

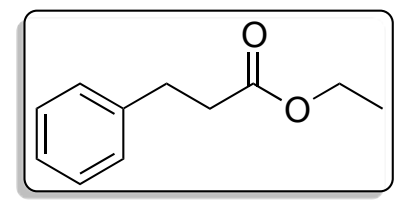

Ethyl 3-phenylpropionate: Colorless solid. ${ }^{1} \mathrm{H}$ NMR (400 MHz, $\left.\mathrm{CDCl}_{3}\right): \delta=$ $7.15-7.55(\mathrm{~m}, 5 \mathrm{H}), 4.18(\mathrm{q}, \mathrm{J}=7.2 \mathrm{~Hz}, 2 \mathrm{H}), 2.96(\mathrm{t}, \mathrm{J}=8 \mathrm{~Hz}, 3 \mathrm{H}), 2.64(\mathrm{t}, \mathrm{J}$ $=8 \mathrm{~Hz}, 2 \mathrm{H}), 1.35(\mathrm{~m}, 3 \mathrm{H}) \mathrm{ppm}$.

\footnotetext{
${ }^{13}$ Hironao, S.; Shigeki, M.; Ohkubo, T.; Ikawa, T.; Kume, T.; Maegawa, A.; Tomohiro, M.; Yasunari, M. Chem. Eur. J. 2008, 14, 51095111.

${ }^{14}$ Hamed, O.; Henry, P. M.; Becker, D. P. Tetrahedron Lett. 2010, 3514-3517.

${ }^{15}$ Petit, C.; Lixon, P.; Pileni, M. P. J. Chem. Phys. 1993, 97, 12974-12983.

${ }^{16}$ Zhang, S. Y.; Tu, Y. Q.; Fan, C. A.; Jiang, Y. J.; Shi, L.; Cao, K.; Zhang, E. Chem. Eur. J. 2008, 14, 10201- 10205.
} 